\title{
Analytical issues in the study of verb-noun compounds: How does Akan fit in?
}

\author{
Clement Kwamina Insaidoo Appah \\ University of Ghana \\ cappah@ug.edu.gh
}

\begin{abstract}
This paper highlights three issues in the study of verb-noun compounding and shows how data from Akan (Niger-Congo, Kwa, Ghana) help answer the relevant questions for the language. The issues, which mainly concern the exocentric subtype, are: one, the syntactic category of the left-hand constituent and that of the whole compound; two, whether the formation of verb-noun compounds is a matter of syntax or morphology; and three, how to distinguish between verb-noun compounds and verb phrases, given their structural similarity. Although these issues have come up somehow in the literature on Akan verb-noun compounds, they have not been deliberately targeted for discussion. This paper fills the gap. It is shown that the left-hand constituent is definitely a verb. This raises the question of how to account for the syntactic category of the exocentric subclass of the compound, given that the compound is not a hyponym of the right-hand nominal constituent whose syntactic category may be assumed to percolate to the whole. It is also argued that, per the criteria in the literature, the formation of Akan verb-noun compounds has to be a matter of morphology and not syntax. Finally, it is shown that there are formal and semantic basis for distinguishing verb-noun compounds from verb phrases in Akan.
\end{abstract}

Keywords: Akan; compositionality; syntactic category; verb-noun compound; Verb phrase

\section{Introduction}

The purpose of this paper is to highlight three central theoretical issues in the study of Verb-Noun (henceforth, V-N) compounds and to show how data from Akan (Niger-Congo, Kwa, Ghana) help us answer the relevant questions for the language. The theoretical discussion in this paper builds on descriptive work done in Appah (2016) which was based on data drawn from a variety of sources which are described below in section 2 .

$\mathrm{V}-\mathrm{N}$ compounds are not very common in the languages of the world, except in Romance languages. However, they have theoretically interesting properties that have engaged the attention of researchers (cf. Marchand 1969; Bauer 1980; 1983; Contreras 1985; Di Sciullo \& Williams 1987; Corbin 1992; Lieber 1992; Scalise 1992; Braun 2009; Fradin 2009; Kornfeld 2009; Yoon 2009; Basciano et al. 2011; Appah 2016; Desmets \& Villoing 
2009; Gast 2008). For example, in their account of V-N compounding, Basciano et al. $(2011,218)$ observe that such compounds "represent a challenging phenomenon for contemporary grammar theory". One reason given for this observation is that $\mathrm{V}-\mathrm{N}$ compounds in the three languages that they study are exocentric, lacking structural and semantic heads, and thus defying the endocentricity principle underpinning Merge (cf. Chomsky 1995). It has to be pointed out, though, that there are endocentric $\mathrm{V}-\mathrm{N}$ compounds as well (Appah 2016; Gast 2009). However, like other endocentric compounds, accounting for the syntactic category of endocentric $\mathrm{V}-\mathrm{N}$ compounds is pretty straightforward because their nominals syntactic category can be assumed to emanate from their right-hand constituents of which they tend to be hyponyms.

Another potentially challenging set of features of $\mathrm{V}-\mathrm{N}$ compounds is the nature as well as the formal and semantic relations between the constituents (Basciano et al. 2011; Desmets \& Villoing 2009), and also the overall semantics of the compound. For instance, it has been observed that $\mathrm{V}-\mathrm{N}$ compounds tend to have negative meanings/connotations and are used in pejorative, derogatory, coarse, vulgar and/or playful/humorous contexts (Marchand 1969; Basciano et al. 2011; Appah 2016; Gast 2009).

Generally, we find three core issues that researchers have sought to deal with in discussing $\mathrm{V}-\mathrm{N}$ compounding. The first issue concerns the form and syntactic category of especially the left-hand constituents and, by extension, that of the whole compound. This issue is relevant for the exocentric subclass of $\mathrm{V}-\mathrm{N}$ compounds and is important because most analysts typically adopt a source-oriented perspective (cf. Zager 1981), where properties of a complex form derive compositionally from its constituents. This perspective suggests that we should expect the head of the nominal $\mathrm{V}-\mathrm{N}$ compound to be a noun. Yet, the first constituent of the compound, which is the selecting element in the corresponding verb phrase, is a verb and, the whole compound is not a hyponym of the right-hand nominal constituent. Therefore, for the exocentric subgroup, it is important, to answer the question of whether the left-hand constituent is nominalized prior to becoming part of the compound, thus making it a Noun-Noun (N-N) compound, or there exists a post-compounding nominalization process that turns a compound of some other syntactic category into a noun (cf. Bauer 1980; Di Sciullo \& Williams 1987; Corbin 1992; Lieber 1992; Ackema \& Neeleman 2004). This is particularly interesting for Akan, because Akan compounds are invariably nominal (cf. Christaller 1875; Dolphyne 1988; Anyidoho 1990; Anderson 2013). Therefore, we need to be able to tell how the exocentric $\mathrm{V}-\mathrm{N}$ compounds become nouns, where there is no head with matching nominal features. 
The second issue relates to the question of whether the formation of $\mathrm{V}-\mathrm{N}$ compounds is a matter of syntax or morphology. This engenders interesting theoretical debates, which ultimately hinges on the analyst's view of the nature of the relationship between morphology and syntax (Di Sciullo \& Williams 1987; Corbin 1992; Lieber 1992; Scalise 1992; Fradin 2009; Kornfeld 2009; Appah 2015). In fact, there seems to be no theoryneutral way of discussing this issue. It is, therefore, fair to suggest that this question is important mainly for analysts who assume a modular view of grammar, where morphology and syntax are strictly segregated modules of grammar.

The third issue, which is closely related to the second one, has to do with how to clearly distinguish between a $\mathrm{V}-\mathrm{N}$ compound and a verb phrase (VP), given the fact that the syntactic category and order of constituents in $\mathrm{V}-\mathrm{N}$ compounds pattern after the verb-object word order in languages that have V-N compounds (cf. Dolphyne 1988; Fradin 2009; Kornfeld 2009; Yoon 2009; Basciano et al. 2011; Appah 2016; Gast 2009). I will argue that, aside from what the regular tests for lexical integrity or syntactic atomicity reveal about the wordhood of the $\mathrm{V}-\mathrm{N}$ constructs at issue, there are three reasons why the Akan $\mathrm{V}-\mathrm{N}$ constructs have to be regarded as compounds and not phrases. First, they tend to be semantically opaque, whilst phrases are usually compositional. Secondly, we do not find verbal inflection on the verbs in $\mathrm{V}-\mathrm{N}$ constructs, although inflectional marking on verbs is obligatory in Akan syntactic constructions, except where the event designated is stative or habitual. Thirdly, a particular tonal melody marks the exocentric subclass of $\mathrm{V}-\mathrm{N}$ compounds to the exclusion of analogous Akan VPs.

The rest of the paper is organized as follows: In section 2, I present a summary of the descriptive facts of Akan V-N compounds, as discussed in Appah (2016). The main point of this paper is dealt with in section 3 , which covers the three core issues mentioned above. I review how the issues have been dealt with in the literature and then show how the relevant questions can be answered for Akan. Section 4 concludes the paper.

\section{Akan V-N compounds and their properties}

Akan V-N compounds have been studied for nearly a century and a half (cf. Christaller 1875; Dolphyne 1988; Abakah 2006). The various strands of research have recently been brought together in a study by Appah (2016). In this section, I review important parts of that paper, to provide the needed background to the present study, focusing mainly on the data adduced 
to support the arguments therein. I do not present any new argument or attempt to defend the claims made in that paper about Akan $\mathrm{V}-\mathrm{N}$ compounds, except where the particular point is important for the focus of this paper. ${ }^{1}$

Beginning from Christaller (1875), many constructs had been posited as exemplars of V-N compounds. However, Appah (2016) observing that true Akan $\mathrm{V}-\mathrm{N}$ compounds usually have simplex consonant-initial lefthand verbal constituents and right-hand noun constituents, which are also mostly simplex, showed that only the twelve constructs in Table 1 qualify as $\mathrm{V}-\mathrm{N}$ compounds out of the many posited. ${ }^{2}$

Table 1: V-N compounds in the Akan literature (Christaller 1875; Dolphyne 1988; Abakah 2006)

\begin{tabular}{|c|c|c|c|c|}
\hline & Compound & Constituents & Gloss & Translation \\
\hline 1 & kyéàdéé & kyéc-àdéé & to share-thing & 'generous person' \\
\hline 2 & bóàdéé & bó-àdéé & to make-thing & 'creator' \\
\hline 3 & kóàyíé & kó-àyíé & to attend-funeral & 'one who attends funerals regularly' \\
\hline 4 & díàbóró & dí-àbóró & to use-malice & 'malicious person' \\
\hline 5 & sùmá'séḿ & sùmà-àsćḿ & to hide-matter & 'secret/a matter which is hidden' \\
\hline 6 & gyìná béá & gyìnà-żbèá & to stand-place & 'standing place'/'status'/'position' \\
\hline 7 & dàbéré/dàbéẃ & dá-béré & to sleep-place & 'place to lie on'/'sleeping place' \\
\hline 8 & tèbèá & té-bèá & to live-manner & 'state/(living) condition' \\
\hline 9 & twá!bó & twá-bó & to cut-stone & 'a stone by which gold is tried' \\
\hline 10 & yébèá & yé-bèá & to do-manner & 'manner of doing' \\
\hline 11 & tràa'béá & tr̀à-bèá & to sit-place & 'a place to sit' \\
\hline 12 & sùsú!dúá & sùsù-dùá & to measure-stick & $\begin{array}{l}\text { 'a measure'/'a stick which they take } \\
\text { and measure things' }\end{array}$ \\
\hline
\end{tabular}

${ }^{1}$ I am grateful to a reviewer for the close reading of the content of this section of this paper and the many suggestions for modification. However, given that this section is simply a review of previous work to provide the needed background to the present study, any suggestion that does not have a bearing on the focus of the present study is not dealt with.

${ }^{2}$ The tone marks on all the constructs and their constituents are the surface tonal melodies.

${ }^{3}$ This verb is used only in the context of gift giving. That is, whatever is given when this verb is used is never expected back from the recipient. 
The remaining constructs in (1) from Christaller (1875, 26-27), (2) from Dolphyne (1988, 123) and (3) from Abakah (2006, 20) are not $\mathrm{V}-\mathrm{N}$ compounds.

(1) Christaller's (1875) exemplars of Akan V-N compounds

$\begin{array}{llll}\begin{array}{l}\text { Compound } \\ \text { akyede }\end{array} & \text { Constituents } & \text { Gloss } & \text { Translation } \\ \text { atuboa } & \text { a-tu-boa } & \text { NMLZ-dash-thing } & \text { 'a gift' } \\ \text { atesem } & \text { a-te-sem } & \text { NMLZ-hly-animal } & \text { 'an animal which flies' } \\ \text { ahenne }(\varepsilon) & \text { a-hen-ne }(\varepsilon) & \text { NMLZ-king-thing } & \text { 'a word heard, hearsay' } \\ \text { ahensem } & \text { a-hen-scm } & \text { NMLZ-king-matter } & \text { 'a king's doings' } \\ \text { atetede } & \text { a-tete-de } & \text { NMLZ-ancient-thing } & \text { 'a thing of the old time' } \\ \text { atetesem } & \text { a-tete-sem } & \text { NMLZ-ancient-matter } & \text { 'a story of ancient times' }\end{array}$

(2) Dolphyne's $(1988,123)$ exemplars of Akan V-N compounds

$\begin{array}{llll}\text { Compound } & \text { Constituents } & \text { Gloss } & \text { Translation } \\ \text { àyédé } & \text { à-yé-àdé } & \text { NMLZ-do-thing } & \text { 'object' } \\ \text { àtúbóá } & \text { à-tú-àbóá } & \text { NMLZ-fly-animal } & \text { 'a fly' } \\ \text { àséń!núá } & \text { à-séń-núá } & \text { NMLZ-hang-tree/wood } & \text { 'crucifix' } \\ \text { àbódíń } & \text { và-bó-díń } & \text { NMLZ-call-name } & \text { 'title' }\end{array}$

The reasons for excluding these exemplars are varied (Appah 2016, 6-8). First, the constructs in (1) and (2) are excluded because their left-hand constituents, which are otherwise simplex and consonant-initial when they occur in isolation, bear affixes in the complex forms. If the prefixes are removed, the remainder do not constitute well-formed compounds. For example, à-kyź-dé (1a) and àyźdé (2a), without their prefixes, become ill-formed (i.e., *kyźdé and *yédé), although in isolation, the verbs are consonantinitial (i.e., kyé 'to gift' and *yé 'to do'). This is what distinguishes these constructs and all others in (1) and (2) from the $\mathrm{V}-\mathrm{N}$ compounds in Table 1, which do not require affixes to be well-formed (cf. Appah 2016, 8).

In the same way, each construct in (3) has either a suffix (3a) or a prefix (3b-d), which appears to nominalize a VP (cf. Appah 2016, 8). Thus, they are not $\mathrm{V}-\mathrm{N}$ compounds.

(3) Abakah's (2006, 20) exemplars of Akan V-N compounds

$\begin{array}{llll}\text { Compound } & \text { Constituents } & \text { Gloss } & \text { Translation } \\ \text { nìmdèć } & \text { nímú-àdé-( }(\varepsilon) & \text { know-a thing-NMLZ } & \text { 'knowledge' } \\ \text { àpàgyá } & \text { à-pá-ògyá } & \text { NMLZ-strike-fire } & \text { 'a thing for striking fire/matches' } \\ \text { èbìsádzé } & \text { è-bísà-àdzé } & \text { NMLZ-ask-thing } & \text { 'a request' } \\ \text { ǹkàsàànímú } & \text { ǹ-kàsà-ànímú } & \text { NMLZ-speak-face } & \text { 'rebuke/chiding' }\end{array}$


The point really is that the affixes that appear on the rejected exemplars are nominalizing affixes and not the regular nominal affixes in Akan which may mark number and are usually optional. Indeed, some of the actual V-N compounds, like (j)bóàdéć 'creator', bear such nominal affixes, which are optional, because they are not nominalizing. As will be discussed in section 3.1 , the nominal syntactic category of the $\mathrm{V}-\mathrm{N}$ compound has been suggested to be a holistic property that is inherited from the compounding process in Akan which is a nominalization strategy (cf. Appah 2015). Thus, there is no need for such obligatory nominalizing affixes in Akan compounds.

Secondly, some exemplars must be excluded from the list of Akan V-N compounds because they "simply do not match the descriptions they are supposed to instantiate" (Appah 2016, 8). The constructs in (1d-g), for instance, do not contain verbs. This is interesting, because Christaller (1875, 26-27) described the parent group of these compounds as "[c]ompounds of a noun with an attributive noun in the possessive case before it". This would make them N-N compounds (cf. Appah 2016, 8). What is puzzling, however, is that Christaller also argues that "[t]he qualifying component is a verb" that "must be rendered by an adjective sentence" (Christaller 1875, 26), suggesting that the verbs correspond to adjectives in English. Obviously, Christaller does not offer any clarity on the matter.

Regarding Dolphyne's description of these compounds as "verb plus object compounds" (Dolphyne 1988, 123), Appah (2016) observed that that is not totally accurate because, in exemplars like àtúbóa 'a fly' and àsénnnúa 'crucifix' in (2), the noun constituents are not objects of the verbs, but heads of relative clauses, as shown in $(4 a-b)$.

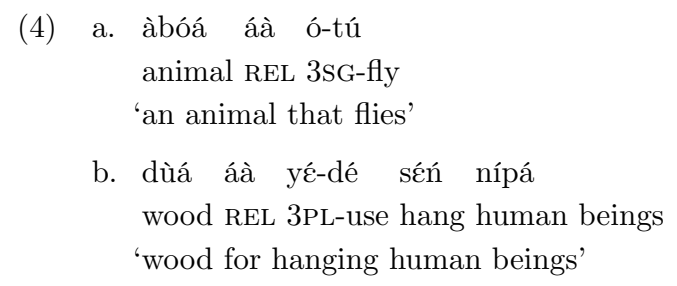

Finally, on the question of tone in such compounds, Dolphyne (1988) and Abakah (2006) gave conflicting accounts. Whilst Dolphyne observed that, notwithstanding its tonal pattern in isolation, the verb constituent is invariably high, Abakah argued that the first constituent is invariably realized on low tone in the compound. The data, however, do not support 
either position. Appah (2016) observed that tone may indeed be used to distinguish some members of this class of compounds from phrases (see (22)), but the tonal pattern of the first constituents of $\mathrm{V}-\mathrm{N}$ compounds is a bit more diverse than presented in previous literature.

Given the foregoing, Appah (2016) made two observations: one, that previous accounts were not adequately thorough; two, that Akan $\mathrm{V}-\mathrm{N}$ compounds are not as productive as previous accounts presented them, because out of the 27 putative $\mathrm{V}-\mathrm{N}$ compounds posited by the three scholars (Christaller 1875; Dolphyne 1988; Abakah 2006), only 12 (44.4\%) of them (Table 1) are $\mathrm{V}-\mathrm{N}$ compounds, the rest were simply misclassified.

Appah (2016) provided additional examples of $\mathrm{V}-\mathrm{N}$ compounds from a variety of sources, including the Akan translation of the Universal Declaration on Human Rights, a children's reader on fishing, and an Akan translation of Plato's apology of Socrates. The set of Akan V-N compound data were subjected to different levels of formal and semantic analysis, yielding varying classes of Akan $\mathrm{V}-\mathrm{N}$ compounds. Concerning the form of the constituents, it is shown that both of them tend to be simplex forms and that the nouns may be the subject or the object of the verb, depending on their transitivity status. However, a few of the nouns are not core arguments of the verb but adjuncts, naming, for example, the location of the action/event designated by the verbal constituent (cf. Appah 2016, 11-12).

Various semantic classes of $\mathrm{V}-\mathrm{N}$ compounds are distinguished based on the relation between the constituents. They are compounds in which the noun constituent may be the location of the action or event designated by the verb, the affected object, the instrument used for the action of the verb, etc. These are summarised in (5).

(5) Semantic patterns in Akan V-N compounds (Appah 2016, 13-14)

a. V-N compounds, where $\mathrm{N}$ is location of action/event $\mathrm{V}$

\begin{tabular}{|c|c|c|}
\hline dá-àmòná & to sleep-hole & 'an animal which dwells in a hole' \\
\hline ká-àkyíré & to remain-behind & 'lastborn/youngest family member' \\
\hline tò-béẃ & to put-place & 'location (where something is put)' \\
\hline dà-dùà & to lie-wood & 'imprisonment/incarceration' \\
\hline dà-béré & to lie-place & 'position/sleeping place' \\
\hline dì-bèá & to assume-place & 'position/rank' \\
\hline tè-bèá & to live-place/nature & 'state/(living) condition' \\
\hline gyìná-béẃ & to stand-place & 'position/standing place' \\
\hline tèná-bèá & to sit-place & 'sitting place' \\
\hline
\end{tabular}


b. V-N compounds, where $\mathrm{N}$ undergoes or is affected by action/event $\mathrm{V}$
i. kúm̀-kóḿ
to kill-hunger
'hunger killer/a species of maize'
ii. kyé-àdéé
to share-thing
'generous person'
iii. kó-ǹsúó to fetch-water
'one who fetches water'
iv. bó-òtíré
to hit/plait-hair
'one who plaits hair'
v. sùmá-séḿ
to hide-matter
'secret'

c. V-N compounds, where $\mathrm{N}$ is used for/in action $\mathrm{V}$
i. sùsú-dùá
to measure-stick
'standard/yardstick/measuring rod'
ii. dí-àbóró
to use-malice
'malicious person'
i. bó-ǹsúó
to hit-water
'professional car wash(er)'
iii. twá-'bó
to cut-stone
'a stone by which gold is tried'

d. V-N compounds, where $\mathrm{N}$ is created by/results from action/event $\mathrm{V}$
i. kyé-péń
to share-portion
'portion/lot/allotment'
ii. bó-àdéé
to create-thing 'creator'

e. $\mathrm{V}-\mathrm{N}$ compounds, where $\mathrm{N}$ is the goal of action $\mathrm{V}$

i. kó-àyíe to attend-funeral 'one who attends funerals'

The final distinction is the crucial one between endocentric $\mathrm{V}-\mathrm{N}$ compounds, where the whole compound is a hyponym of the right-hand constituent, as in (6), and exocentric $\mathrm{V}-\mathrm{N}$ compounds, presented in (7), which are not hyponyms of either constituent.

(6) Endocentric V-N compounds in Akan (Appah 2016, 14-16)
a. sùsú-dùá to measure-stick
'standard/yardstick/measuring rod'
b. tò-béẃ to put-place
c. dà-béré to lie-place
'location (where something is put)'
d. kyé-pén
to share-portion
'position/sleeping place'
e. dì-bèá
to assume-place/rank
'portion/lot/allotment'
f. tè-bèá
to be-manner/nature
'position/rank'
g. gyìná-béẃ
to stand-place
h. sùmá'sćm
to hide-matter
'state/(living) condition'
'position'
'secret'
i. twá-'bó to cut-stone
j. tèná-bèá
to sit-place
'a stone by which gold is tried'
'sitting place'

(7) Exocentric V-N compounds in Akan (idem.)
a. dá-àmòná to sleep-hole
'an animal which dwells in a hole'
b. dà-dùà to lie-wood
'imprisonment/incarceration'
c. ká-àkyíré to remain-behind
'lastborn/youngest family member'
d. kó-àyíé
to attend-funeral
'one who attends funerals'
e. kúm-kóm
to kill-hunger
f. kyć-àdéé
to share-thing
'hunger killer/a species of maize'
'generous person' 


$\begin{array}{llll}\text { g. bó-ǹsúó } & \text { to hit-water } & \text { 'professional car wash(er)' } \\ \text { h. kó-ǹsúó } & \text { to fetch-water } & \text { 'one who fetches water' } \\ \text { i. bó-òtíré } & \text { to hit/plat-hair } & \text { 'one who plaits hair' } \\ \text { j. dí-àbóró } & \text { to use-malice } & \text { 'malicious person' } \\ \text { k. bó-àdéé } & \text { to create-thing } & \text { 'creator/one who creates things' }\end{array}$

The core issues that are discussed in the next section are based on the data discussed in this section.

\section{The analytical issues in the study of $\mathrm{V}-\mathrm{N}$ compounds}

In this section, I discuss the three analytical issues in the study of $\mathrm{V}-\mathrm{N}$ compounds, relating to the syntactic category of the left-hand constituents and of the whole compound (section 3.1), whether the formation of $\mathrm{V}-\mathrm{N}$ compounds is a matter of syntax or morphology (section 3.2) and how $\mathrm{V}-\mathrm{N}$ compounds may be differentiated from VPs (section 3.3). In each case, I first present the arguments in the literature and then show which position the Akan data lead us to support.

\subsection{On the syntactic category of the left-hand constituents of $\mathrm{V}-\mathrm{N}$ compounds $^{4}$}

The issue of the word class of the left-hand constituent of $\mathrm{V}-\mathrm{N}$ compounds has been topical in the literature and it is very important for understanding the properties of the exocentric subclass of $\mathrm{V}-\mathrm{N}$ compounds. One reason why it is important to know the categorial affiliation of the left-hand constituents of $\mathrm{V}-\mathrm{N}$ compounds, is language-internal facts. It is clear from the literature that usually the left-hand constituent is simplex (Basciano et al. 2011; Fradin 2009; Kornfeld 2009; Braun 2009; Appah 2016). Therefore, for languages that have mostly multifunctional V/N lexical items like Sranan (Braun 2009) or make extensive use of conversion like English (Bauer 1983; Gast 2008; Plag 2003), it is important that we have criteria for determining the lexical category of the left-hand constituent.

Some scholars, working mainly on Romance languages, hold the view that the left-hand constituents are nominalized, thus making them endocentric N-N compounds (cf. Scalise et al. 2005, 140; Rainer \& Varela 1992; Bisetto 1999). Some argue, for example, that the left-hand constituents

\footnotetext{
${ }^{4}$ This section builds on ideas in Appah (2016, 21, n. 2).
} 
are agentive nominals which results from the deletion of agentive suffixes (Bisetto 1999) or the reanalysis of a previous inflectional suffix (Varela 1990).

Other scholars hold the view that the left-hand constituent is a verb and the head of a VP which acquires morphological structure through a reanalysis rule that turns VPs into nouns, yielding $\left[[\mathrm{V} \mathrm{N}]_{\mathrm{VP}}\right]_{\mathrm{N}}$ (Di Sciullo \& Williams 1987, 79-83). The problem with this view, as pointed out in the literature, is that proponents "provide no independent evidence for the existence of such a reanalysis rule" (Braun 2009, 184). On her part, Lieber $(1992,67)$ argues for a zero nominal(izing) affix which turns an underlying VP into a noun, giving $\left[[\mathrm{V} \mathrm{N}]_{\mathrm{VP}} \emptyset\right]_{\mathrm{N}}$, as in the case of French essuie glace 'windshield wiper', whose structure is discussed in section 3.2. This nominalization-of-VP-by-zero view is shared by Contreras (1985).

For Sranan, Braun $(2009,183)$ decided in favour of a verbal left-hand constituent for two reasons: first, a number of them are attested only as verbs in the sources of her data, and second, because all of them denote actions. The problem with the latter reason, however, is that it fails to acknowledge the fact that actions may also be expressed by action nominals (Comrie 1976; Koptjevskaja-Tamm 1993; 2006; Appah 2005), also called event/process nominals (Grimshaw 1990; Melloni 2006; 2007; 2010).

For those who hold the view that the left-hand constituent is a verb, there may be the added concern of determining the actual form of the verb, whether it is a root or a stem, if such a distinction is relevant in the language (Basciano et al. 2011; Bauer 1980; Fradin 2009; Kornfeld 2009). For example, for the Bantu language Bemba, Basciano et al. (2011, 221) argued that the $\mathrm{V}-\mathrm{N}$ compound is formed by "conjoining a verbal stem, i.e., a verb root followed by a final vowel (formally matching the vowel attested in fully inflected verbs)". A similar analysis is presented for Romance V-N compounds, which are said to be "formed by a verbal root plus a final vowel" (Basciano et al. 2011, 231), with on-going debate on whether it is a verbal theme (a stem plus a theme vowel) or the second person singular form of the imperative or the third person singular form of the present indicative (cf. Tollemache 1945; Varela 1990). For French V-N compounds, Desmets and Villoing (2009) argue that the verb forms have to be regarded as stems, based on their phonological properties. This is because the $\mathrm{V}-\mathrm{N}$ verb forms are not marked for inflection. They observe that verbal lexemes are associated with a vector of different possible phonological representations and that "[t]he first stem is the default phonological stem for all verbs involved in the VN compounding rule" (Desmets \& Villoing 2009, 95). 
We see then that, mainly formal criteria are employed in identifying the syntactic category of the left-hand constituents of $\mathrm{V}-\mathrm{N}$ compounds. The absence of semantic criteria was already noted by Yoon (2009) regarding studies on Spanish V-N compounds, when he writes that "few have taken into account the semantic properties of the $[\mathrm{V}+\mathrm{N}]$ compound in Spanish" (ibid., 508). In their discussion of French V-N compounds Desmets and Villoing (2009) did not deviate very much from other researchers who do not pay much attention to the semantics of the constituents of the compound, especially the verb, aside from the observation that the verbal base lexeme of a $\mathrm{V}-\mathrm{N}$ compound is dynamic, transitive and presents an agent/patient relation. I will also not deviate very much from previous approaches because relying on the form would serve us better than meaning because, as noted above, the same meaning may be expressed by two separate syntactic categories without a change in form.

The question of the categorial affiliation of the left-hand constituent of Akan V-N compounds has not been discussed directly, beyond Christaller (1875). Dolphyne (1988), Abakah (2006) and Anderson (2013) do not discuss the categorial status of the left-hand constituents, but we can tell that they regard them as verbs, because they use the labels verb-noun and verb-object compounds. However, as noted in section 2, Christaller's view on this matter lacks clarity because Christaller (1875, 26-27) first groups the compounds at issue and some others under a broad category he characterizes as "[c]ompounds of a noun with an attributive noun in the possessive case before it" [emphasis is original]. Within this group, he places $\mathrm{V}-\mathrm{N}$ compounds under subgroup (b) about which he writes: "[t]he qualifying component is a verb; on dissolving such compounds the verb must be rendered by an adjective sentence" (ibid., 26). Thus, it is unclear whether Christaller regards the left-hand constituent as a verb, which is interpreted as an adjective, or as a deverbal noun with attributive function. Akan indeed has (stative) verbs which are rendered as adjectives in English, but the verbs that occur in these compounds e.g., dá 'to sleep', ká 'to remain' and kó 'to go') do not belong to that class of verbs.

We see, then, that whilst tacitly agreeing that they are verbs, previous studies provide no evidence for this, making them not particularly helpful for the purpose of determining the syntactic category of the left-hand constituents.

Appah (2016) argued that there is no formal or semantic basis for assuming the deverbalization of the left-hand constituents of Akan V-N compounds because, as argued in section 2, the left-hand constituents of these compounds bear no formal marks of nounhood. For example, nominalized 
$d a ́$ 'to sleep' and sùsù 'to measure' in (8) would be ǹ-dá 'sleep(ing)' and ̀̀-sùsú-i 'measuring' respectively and the nasal nominal(izing) prefix is not optional. Therefore, to assume a nominal left-hand constituent in the well-formed compounds, without the nasal nominalizer, would be to claim that the nominal is formed through conversion. However, conversion has a rather doubtful status in Akan (cf. Appah 2013b), because all posited instances of conversion or functional change (cf. Obeng 2009, 107-108) are accompanied by tonal changes which may be deemed to be responsible for the category change. This suggests that, in the absence of any evidence of nounhood in the form of tonal changes, we may assume that a bare recognised verbal base has not changed its syntactic category.

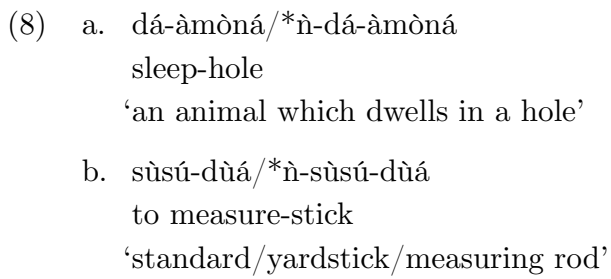

It has to be recalled that the left-hand constituents of those constructs that were excluded from the class of $\mathrm{V}-\mathrm{N}$ compounds (section 2) bear affixes that show that they are not verbs and so the constructions they occur in cannot be $\mathrm{V}-\mathrm{N}$ compounds.

Given the fact that the left-hand constituents of Akan V-N compounds are bare, the careful reader would point out that, strictly speaking, there are no marks of verbhood on them either. Indeed, it seems to me that the reason why there are no tense/aspect, mood and polarity (TAMP) markers on the left-hand constituents of the $\mathrm{V}-\mathrm{N}$ compounds is that it is the stem of the verb which forms the compound, much in agreement with the view that Akan "[c]ompounds are made up of two or more stems" (Dolphyne 1988, 117). Besides, it is possible to deduce from the distribution of the bases that they are verbs because they can occur in syntactic constructions, still without any formal TAMP marking when designating habitual or stative events. This is shown in (9), where the verbs in the stative and habitual construction bear no tense/aspect markers, unlike those in the progressive and future constructions, which carry rè- and bé- as their respective markers.
(9) a. Kofi sùsú
dùá.
Kofi measure.HAB stick
'Kofi measures a stick.' 


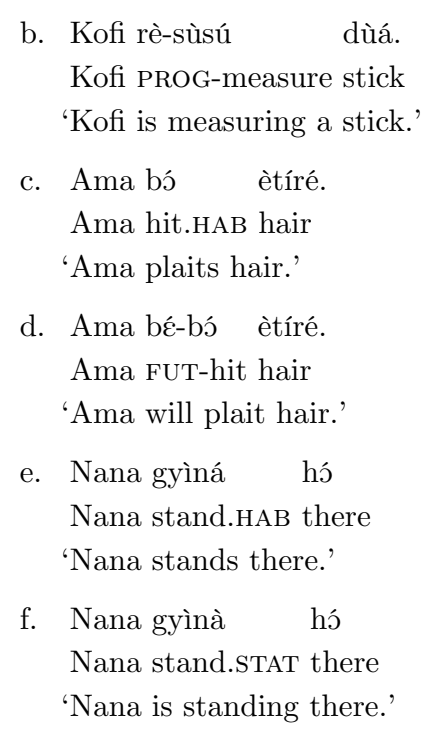

This approach of using distribution to determine the syntactic category of the left-hand constituent is consistent with the approach in Braun (2009) where, based on their syntactic distribution, she decided that what appeared to be multifunctional $\mathrm{V} / \mathrm{N}$ lexical items should be regarded as verbs because the forms in question are deployed in syntactic structure as verbs and not nouns. Thus, by means of their form and syntactic distribution, we have been able to show that the left-hand constituents of the Akan compounds at issue are verbs. This conclusion would still hold for Akan, even in the absence of verbal inflection on the left-hand constituents of the constructs under discussion.

For endocentric $\mathrm{V}-\mathrm{N}$ compounds, this question of the syntactic category of the left-hand constituent is inconsequential because there is a head which ordinarily would be assumed to be the source of the nominal syntactic category. However, for the exocentric $\mathrm{V}-\mathrm{N}$ compounds, establishing the verbal status of the left-hand constituent raises the question of how they receive their nominal syntactic category, given that they are not hyponyms of their right-hand nominal constituents. Here, it is worth noting that the issue of the syntactic category of Akan compounds in general has been dealt with in the literature. Appah (2015) has argued that because Akan compounds are invariably nominal, notwithstanding the syntactic category of the constituents, we have to assume that the nominal syntactic category is a property of Akan compounds per se. In other words, compounding in Akan is a nominalization strategy. Hence, no matter the category of the input, the output will be a noun; even two verbs forming a compound in 
Akan will result in a noun (Dolphyne 1988; Abakah 2006; Anderson 2013; Appah 2015). Thus, for Akan, whilst it is good to determine the syntactic category of the constituents, that determination is not at all needed for the purpose of ascertaining the source of the nominal syntactic category of the compound.

This is where the issue of the syntactic category of the left-hand constituents of $\mathrm{V}-\mathrm{N}$ compounds shows differential significance for Akan as against other languages that have $\mathrm{V}-\mathrm{N}$ compound. Generally the exocentricity of the relevant compounds in based on the fact that the most important element of the compound is a verb whilst the compound is a noun (cf. Basciano et al. 2011; Corbin 1992; Gast 2009; Lieber 1992), thus, as noted above, knowing the syntactic category of the left-hand constituent is crucial to the task of determining the syntactic category of the compound in languages that have $\mathrm{V}-\mathrm{N}$ compounds, but for Akan the output syntactic category is known, ab initio.

\subsection{On constructing V-N compounds: syntax or morphology}

The question of whether $\mathrm{V}-\mathrm{N}$ compounds are formed in the syntax or in the lexicon engenders interesting theoretical debates among morphologists who assume a modular view of grammar, where morphology and syntax are two strictly ordered modules (cf. Rohrer 1977; Di Sciullo \& Williams 1987; Lieber 1992; Corbin 1992; Ackema \& Neeleman 2001; 2004; Fradin 2009). In the languages of the world, both the syntactic formation and the pre-syntactic lexical formation of $\mathrm{V}-\mathrm{N}$ compounds have been defended.

In the Romance languages, scholars have attempted to find ways of determining whether a particular $\mathrm{V}-\mathrm{N}$ construct is formed syntactically or lexically. One test formulated by Corbin (1992, 48-49), cited in Fradin (2009, 422), seeks to find out whether the $\mathrm{V}-\mathrm{N}$ construct can occur in a well-formed sentence, where the verb of the $\mathrm{V}-\mathrm{N}$ is the only verb and there is no need for any additional verb. If yes, then there is evidence of syntactic formation. Otherwise, they are assumed to be lexically formed and they are compounds.

With this view comes the suggestion that if a construction is formed syntactically, it cannot be a compound because, for Corbin (1992, 50), units that can be straightforwardly generated by other components of the grammar are not the concern of compounding. This expectation that a compound will not be formed syntactically is encapsulated in what Fradin $(2009,417)$ calls Principle A as stated in (10). 
(10) Principle A (Fradin 2009, 417)

Compounds may not be built by syntax (they are morphological).

It has to be pointed out that Fradin himself believes that "V+N compounds are constructed by morphology" (Fradin 2009, 423).

When one attempts to apply Corbin's (1992) diagnostic, it quickly becomes clear that it is not possible for the Akan $\mathrm{V}-\mathrm{N}$ compound to occur in a sentence where the left-hand $\mathrm{V}$ constituent is the only verb in the construction. Thus, the examples in (11), which are constructed for illustration, are ungrammatical because tó 'to place on/at', which is part of a word, is the only verb in what is supposed to be a syntactic construction.

$$
\begin{aligned}
& \text { (11) a. }{ }^{*} \text { ว̀-tò-béẃ } \\
& \text { 3sG-put-place } \\
& \text { b. }{ }^{*} \text { Kofi tò-béẃ } \\
& \text { Kofi put-place }
\end{aligned}
$$

This test can be applied to all the examples. That is, for each accepted Akan V-N compound, if we added a subject to form a syntactic construction, where the verb in the $\mathrm{V}-\mathrm{N}$ compound is the only verb, the resultant construct would be unacceptable. Where such a construct appears to be acceptable, it would be because, it is a completely different construction and the meaning would show. This is the case for the examples in (12).
(12) a. Kofi sùsú dùá.
Kofi measure.HAB stick
'Kofi measures a stick.'
b. Kofi sùsú-dùá.
Kofi measure-stick
'Kofi's measuring stick (yardstick).'

Example (12a) shows that it may be possible to have a syntactic construction in which the same verb in the compound is the only verb in the construction. The difference, however, is that the resultant construction is completely different, as the meaning ('Kofi measures a sick') shows. Here, again, we assume that the verb is in the habitual because there is no formal marking for any other tense/aspect and the tonal melody is consistent with the habitual. In (12b), where sùsú-dùá is construed as a compound, the subject in (12a) is seen as the possessor of the referent of the compound sùsú-dùa in a possessive construction which means 'Kofi's measuring stick/yardstick'. This confirms that it is not possible to treat the 
compounds at issue as possible syntactic constructions by simply adding a subject NP and treating the constituent verb as the head of a verb phrase.

The example in (13) is interesting in its own way. It is grammatical because there is another verb ( $f a$ ' 'to take') in the construction, which makes it a serial verb construction (cf. Appah 2009), and shows that the verb tó 'to place on/at' rather forms a unit with the other verb. Therefore, we are not dealing with the same $\mathrm{V}-\mathrm{N}$ construct - tò-béw 'location (where something is put).$^{5}$

\section{(13) fá tò bèá há \\ take put place here \\ 'put it here/in this place'}

That (13) is a syntactic (serial verb) construction, is confirmed by the fact that the noun has a separate modifier há 'here', although the lexical integrity principle (Chomsky 1970; Bresnan \& Mchombo 1995; Lieber \& Scalise 2007; Booij 2009) forbids the independent (syntactic) modification of the constituent of a word. With specific reference to compounding, this is encapsulated in the observation that a modifier in a compound will not act "by and for itself" (Ralli \& Stavrou 1998, 244).

The data in (11) to (13) may give the impression that Corbin's diagnostic test works for the Akan data. However, it is not clear that the test shows whether the compound is formed lexically or syntactically. What it really succeeds in doing is confirming the syntactic atomicity of the $\mathrm{V}-\mathrm{N}$ compound. That is, that the compound is a word with lexical integrity, which is violated when the verbal constituent is construed as the main verb of some syntactic construction.

One serious problem with Corbin's approach is that it advocates a firewall between morphology and syntax, where the two modules are strictly segregated and ordered. This is an unsustainable position in the present "theoretical universe", to borrow an expression from Lieber \& Scalise (2007).

As noted above, for Romance examples, some proponents of syntactic derivation assume that there is an underlying VP (cf. Contreras 1985; Di Sciullo \& Williams 1987; Lieber 1992) which is thought to undergo reanalysis (Di Sciullo \& Williams 1987) or be nominalized through zero affixation, as in Lieber's (1992) analysis of the French V-N compound essuie-glace 'windshield wiper' (lit. wipe-windshield), as shown in (14).

\footnotetext{
${ }^{5}$ Note that it is an allomorph of béw (bèa) which occurs in the construction in (13).
} 
(14)

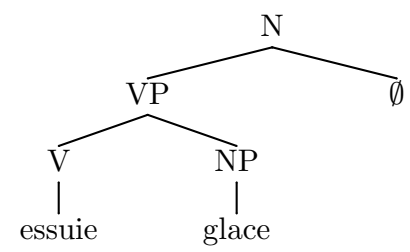

(Lieber 1992, 67)

Commenting on the purported syntactic derivation of $\mathrm{V}-\mathrm{N}$ compounds from underlying VPs in French, Fradin (2009) argues that such an analysis "has to explain why a $\mathrm{V}$ may occur with no morphosyntactic marking although it heads a syntactic VP. [...]. If no marking is assumed, a theory of ellipsis is required, which should make explicit in what situation the deletion of obligatory inflectional marks is licensed" (Fradin 2009, 425). So, for Fradin, the form of the verb in the V-N compound does not quite support the claim of an underlying VP.

Another problem with assuming an underlying VP for $\mathrm{V}-\mathrm{N}$ compounds is that for some of the compounds, the noun constituents can only be interpreted as the external argument, which is outside of the VP. Besides that, some of the nouns are not, strictly speaking, arguments of the verb, but adjuncts, to the extent that they denote, for example, the location of the action designated by the verb (Fradin 2009; Kornfeld 2009). A similar position against an underlying-VP-analysis of $\mathrm{V}-\mathrm{N}$ compounds in Bemba is presented by Basciano et al. $(2011,224)$ who argue that the verb constituents are intransitive and so cannot licence the occurrence of the nouns. Thus, the nouns are not always arguments of the verbs they occur with.

In the literature, we find that another important criterion for determining the non-syntactic nature of the formation of $\mathrm{V}-\mathrm{N}$ compounds is whether the $\mathrm{V}-\mathrm{N}$ construct in question exhibits the properties of lexicalized phrases. This will be shown by the amount of typically verbal or typically nominal features it displays (cf. Fradin 2005; Desmets \& Villoing 2009). For example, Desmets and Villoing (2009) argue that French V-N compounds are not syntactic formations because they do not show the expected properties of lexicalized syntactic phrases. They observe that compounding being a lexical process typically does not involve functional words like determiners, prepositions and pronouns, including clitic forms. However, syntactic lexicalization of verb phrases, including those that involve the same $\mathrm{V}$ and $\mathrm{N}$ categories we find in $\mathrm{V}-\mathrm{N}$ compounds, do characteristically preserve function words. In this regard, they note that the type of nouns found in French $\mathrm{V}-\mathrm{N}$ compounds must appear with determiners in corresponding sentences, whilst determiners are never allowed with the $\mathrm{N}$ in V-N nominals (Desmets \& Villoing 2009, 91). 
The foregoing arguments for rejecting the syntactic derivation of $\mathrm{V}-\mathrm{N}$ compounds in French (Fradin 2009; Desmets \& Villoing 2009) and Bemba (Basciano et al. 2011) can be easily extended to Akan. As noted in section 3.1, the $\mathrm{V}$ in Akan $\mathrm{V}-\mathrm{N}$ constructs are without verbal inflection, which is obligatory in syntactic constructions, and the verb and noun may not be typical sisters in a VP (See further discussion of this in section 3.3). Thus, we take the view that the formation of Akan $\mathrm{V}-\mathrm{N}$ compounds is a matter of morphology because there is no formal evidence to support syntactic derivation.

It is worth stressing that the matter of whether the $\mathrm{V}-\mathrm{N}$ compounds may be assumed to be formed in the syntax or in the lexicon is of interest to only frameworks that assume a modular view of grammar, where morphology and syntax constitute strictly segregated modules which interact in very specific ways so that the output of the former module is the input to the latter (Halle 1973; Scalise 1984; Lieber 1980; Selkirk 1982; Bresnan \& Mchombo 1995; Chomsky 1970). This is the lexicalist view where a word is seen as a syntactic atom whose internal structure is inaccessible to syntax and so syntactic operation involving extraction, such as topicalization and focalization, cannot move any item out of a word, showing that words are islands for extraction. For example, given the compound truckdriver, it is not allowed to move the constituent truck out of the compound truckdriver, for instance, by topicalization (as in * Truck, her father is a driver). In the same way, anaphoric resumption of especially the non-head constituents of a word is not allowed. Here, it is not possible to refer to the constituent truck. Hence, the following construction is unacceptable: Her dad is a truck $k_{i}$-driver, but he doesn't have one $e_{-i}$, where one refers to the truck, meaning '... he doesn't have a truck'. ${ }^{6}$

For two groups which sometimes come under the heading of constructionism in contrast to lexicalism (cf. Fábregas \& Scalise 2012, 133-151), the question of the syntactic or pre-syntactic formation of the $\mathrm{V}-\mathrm{N}$ compound is not interesting. The first group has Distributed Morphology (Halle \& Marantz 1993; 1994; Marantz 1997) and other syntactic approaches to word formation (e.g., Lieber 1992), for which syntax is the only computational engine for the formation of both words and phrases. For this group, there is no difference between the formation of words and the formation of sentence because it is syntactic hierarchical structure all the way down (Halle \& Marantz 1994; Harley \& Noyer 1999). The second

${ }^{6}$ For a recent assessment of the lexical integrity hypothesis, see Lieber \& Scalise (2007) and Booij (2009). 
group for which the question of the syntactic or pre-syntactic formation of $\mathrm{V}-\mathrm{N}$ compounds is not interesting has constructionist frameworks that assumes a continuum view of the relationship between grammar and lexicon and a foundational assumption is that the lexicon or more accurately constructicon (cf. Jurafsky 1992) is a continuum of constructions (cf. Appah 2013b; Booij 2004; 2010a;b; 2012a; Goldberg \& Jackendoff 2004; Masini 2009; Langacker 2005). I hold a constructionist view on this matter of the formation of complex words. However, in this paper, I do not develop this any further because a Construction Morphology account of Akan V-N compounds is provided in Appah (2016, 16-20).

\subsection{Distinguishing between $\mathrm{V}-\mathrm{N}$ compounds and verb phrases}

$\mathrm{V}-\mathrm{N}$ compounds, as the foregoing discussions reveal, are very close to VPs in terms of the syntactic categories and constituent order. Therefore, it is necessary that there exist criteria for distinguishing between $\mathrm{V}-\mathrm{N}$ compounds and other $\mathrm{V}-\mathrm{N}$ constructs that must be analysed as VPs. In the literature, we find attempts made to find such distinguishing criteria. Braun (2009), for example, observes that, although Sranan V-N compounds have the internal structure of VPs, they function as $\mathrm{N}^{0} \mathrm{~s}$ at the level of syntax. She argues that the constructions "can occupy $\mathrm{N}^{0}$ slots because they fulfil a referential function and therefore behave similarly to other naming units which are $\mathrm{X}^{0}$ structures as well" (ibid., 184). Thus, Braun employs the syntactic tool of substitution to establish the nounhood and, for that matter, the syntactic atomicity of the $\mathrm{V}-\mathrm{N}$ compound.

In the literature on lexical integrity, we find various criteria for showing that some phonological string constitutes a word and not a phrase. We mentioned and exemplified some of them in section 3.2 with data from English. They include ban on modification of individual constituents, ban on movement of especially non-head constituents for focus and topicalization and pronominal reference (Bresnan \& Mchombo 1995; Chomsky 1970; Lieber \& Scalise 2007; Selkirk 1982; Williams 1978; Scalise \& Guevara 2005; Spencer 1991; 2005). I will apply the tests of no topicalization/focus and anaphoric reference to parts of words as well as non-modification of individual construction to underscore the wordhood of the Akan V-N constructs at issue.

Typical words resist standard extraction tests like topicalization and focalization to show that words are islands for extraction. When we apply the extraction test to the Akan compounds we end up with ungrammatical structures as shown in the examples in (15) and (16). 
(15) Non-head topicalization in sùmá'sćm 'secret' (6h), kyéàdéé 'generous person' (7f)
a. *àsćm, ò-tùmi sùmá__ matter 3sG-be.able hide
'matter, it can hide'
b. *àdéé déé Kwàkú kyع__ thing TOP Kwaku gift 'as for things/gifts Kweku really gives'

(16) Non-head focus in twá' bó 'a stone by which gold is tried' (6i), kúmkóḿ 'hunger killer' (7e)
a. *j̀bó nà Ábá twá-
matter FOC Aba cut
'It is stone that Aba cuts.'
b. *kóḿ nà Kwàkú kúm _ thing FOC Kwaku gift
'It is hunger that Kweku kills.'

As noted in section 3.2, another criterion is that constituents of words, especially the non-heads, are unavailable for anaphoric resumption and there is a ban on head movement especially involving the non-head. When this test is applied to the Akan data, we end up with ungrammatical structures, as exemplified by the data in (17), where the pronoun bi 'some' in (17a) and $(17 \mathrm{~b})$, refer to the bracketed parts of the compounds and the constructions are ungrammatical because the pronoun refers to constituents of complex words.

(17) Pronominal reference to non-head, sùsú-dùá 'yardstick' (6a), bó-ǹsúón 'professional car wash(er)' (7g)
a. *Ábá wò sùsú-[dua $]_{i} \quad$ nàńsó ò-ǹ-sùsú $\quad$ bì $i$
Aba has measuring stick but
'Aba has a measuring stick but she does not measure some.'
b. *Kwàkú yè bóǹ-[súó $]_{i} \quad$ éńti j̀-bó bì
Kwaku be professional car wash(er) so 3SG-hits some
'Kweku is a "professional car wash(er)" so he washes some.'

The final test we use is the modification test. This test is meant to prove cohesiveness which is one of the defining properties of words (cf. Di Sciullo \& Williams 1987; Dixon \& Aikhenvald 2002a;b; Lyons 1968; Lieber \& Scalise 2007). This test shows that the individual constituents of words, especially the non-head constituents cannot be modified independently. 
This is clear from (18), where, as the bracketing shows, the modifier (e.g., the definite determiner in (18a)) modifies only the right-hand nominal constituents, rendering the construction ungrammatical. This confirms the view that a non-head constituent of as complex word cannot act by and for itself (Ralli \& Stavrou 1998; Giegerich 2004; 2005).

(18) Insertion/modification test
a. *dì [bèá nó]
to assume place/rank DEF
b. *sùmá [séḿ pìi] to hide matter a lot
c. *twá [bó kèsé]
to cut stone large
'cut a large stone'
d. *dá [àmòná kàkraba]
to sleep hole little
'sleep a small hole'
to remain behind small
'little remain behind'
e. *ká [àkyíré ketewaa]
f. *bó [àdéé nyinara]
to create thing all
'create all things'

All the three standard tests for syntactic atomicity applied above returned ungrammatical constructions. This shows that the constructs under discussion are words and, given that the two constituents of the complex words are free forms, we have to conclude that they are compounds.

Aside from the regular tests for the syntactic atomicity of the $\mathrm{V}-\mathrm{N}$ constructs, there are three additional criteria for distinguishing between the Akan V-N compounds discussed in this paper and the corresponding VPs. The first, which relates to the exocentric subtype, is semantic and is based on the notion of compositionality, the general principle for the interpretation of linguistic constructs, which states that the meaning of a complex expression is a compositional function of the meanings of its constituents and how they are combined (cf. Booij 2012b, 209-211; Gendler Szabó 2012; Jenssen 2012; Anderson 1992). That is, whilst the corresponding phrases tend to be compositional, the exocentric $\mathrm{V}-\mathrm{N}$ compounds are non-compositional, so that the meaning of the whole cannot 
be deduced completely from the combination of the meanings of the parts. For example, in (19b), it is not possible to tell the whole meaning of the compound (an animal which dwells in a hole) by combining the meanings of dá 'to sleep' and àmòná 'a hole'. In the same way, one cannot tell that by combining ká 'to remain' and àkyiré 'behind' (20), we would form a compound that refers to the lastborn (the youngest/latest member of a family). Again, we cannot predict that the combination of kúm 'to kill' and kóm 'hunger' would yield a word that refers to a species of maize (19a). As a syntactic construction, kùm kóm means 'to kill hunger' and nothing more, yet the compound is agentive, referring to the entity that performs the action of killing hunger.

(19) a. kúm̀-kóḿ

kill-hunger

'hunger killer (a species of maize)'

b. dá àmòná

sleep hole

'animal which dwells in a hole'

(20) ká-àkyíré

to remain-behind

'lastborn/youngest family/group member'

As Appah (2016, 21, n. 1) points out, "the existence of idiomatic phrases like the verb phrase kick the bucket makes semantic transparency a tricky criterion for distinguishing between compounds and phrases". Indeed, it is not the case that the meanings of the compounds are entirely unrelated to the compositional meanings of the constructions. There are clear metonymic relations between the idiomatic meanings of the compounds and their compositional meanings. For example, in (19a), the action of killing hunger is used to refer to the agent of the action of "killing hunger". In (19b), the location of an entity is used to represent the entity that is associated with the location as its dwelling. Again, the fact of remaining behind or arriving late, relative to a certain time or occurrence, is used to refer to the person who remains behind or arrives late (20).

Commenting on similar relations in French V-N compounds, Fradin writes that " $\mathrm{V}+\mathrm{N}$ compounds are commonly used to express the institutionalized function a human being performs in a society [...] or, simply an activity which allows us to socially identify the compound's referent" (Fradin 2009, 423). This is very true of the Akan compound ká-àkyiré (20), 
which is used exclusively to identify the lastborn of a family or, part in jest, to refer to the last person to join any group/ unit. ${ }^{7}$

In addition to the semantics, unlike VPs to which we can add subject NPs/pronouns and obtain well-formed constructions, à la Corbin (1992) cited in Fradin (2009), it is not possible to simply attach a subject marker to an Akan V-N compound and get a well-formed sentence with the same meaning, as the examples in (11) and (12) show. Related to this is the fact that the $\mathrm{V}$ constituent is stripped of all verbal inflectional markers, which are otherwise formally marked obligatorily in phrases, except when, as indicated above, the construction is in the stative or habitual in which case tone is employed. Recall the examples in (9).

Finally, there is phonological evidence that some of the constructions we are interested in are not phrases. That is, for those exocentric V-N compounds that usually have agentive reading, there is a corresponding VP that differs from the compound in their tonal melodies, as shown in (21).
Related VP
Compound
a. kò ǹsúó
kó-ǹsúó
go water
go-water
'fetch water'
'one who fetches water'
b. bò àdéé
bó-àdéé
creat thing
create-thing
'create thing'
'creator'
c. bò ǹsúó
bó-ǹsúó
hit water
hit-water
'hit with water'
'professional car wash(er)'
d. kùm kóḿ
kúm̀-kóḿ
kill hunger
kill-hunger
'kill hunger'
'hunger killer (a species of maize)'
(Appah 2015, 385)

${ }^{7}$ A reviewer suggests that the interpretive effect of non-compositionality might be due to the fact that such $\mathrm{V}-\mathrm{N}$ constructs are lexicalised with a specific meaning and that a more important question is whether these $\mathrm{V}-\mathrm{N}$ compounds are formed productively in Akan and what the presence of neologisms will reveal about the interpretation. What is clear, in terms of productivity, is that the pattern is definitely available but not profitable, in the sense of Bauer (2001). It is available because we can see relatively recent formations like bóṅúó 'professional car wash(er)', which could only have come into existence with the advent of professional car wash, which is a relatively recent phenomenon. In addition, about two years ago, someone saw the photo of his friend on Facebook in which the friend was sharing soup at a social gathering. The person wrote on that friend's wall jkyźñkwán 'one who shares soups', and the meaning was pretty clear. This shows that the pattern may be used to form new V-N compounds. However, there are very few such V-N compounds formed. Therefore, we can conclude that the pattern is not profitable (cf. Bauer 2001).

Acta Linguistica Academica 66, 2019 
These exocentric V-N compounds (see (7) above) are said on high-lowhigh-high tonal melody consistently, although the analogous phrases in (21) bear varied tonal melodies. The important point to note here is that, whatever the tonal melody of the phrase and of the individual constituents in isolation, the compound will have the observed tonal melody.

To end the discussion, we can make a further point of establishing the nominal status of the Akan $\mathrm{V}-\mathrm{N}$ constructs through their distribution. For example, we know that only nouns may co-occur with determiners, be pluralized and be the possessed element in a possessive phrase. Thus, using ká-àkyiré 'lastborn' ((7c) above) for illustration, we can prove the nominal status of Akan $\mathrm{V}-\mathrm{N}$ compounds, because they can be modified by determiners (22a), co-occur with possessive pronouns $(22 \mathrm{~b})$, be the possessed elements (22c) or inflect for number $(22 \mathrm{~d})$.

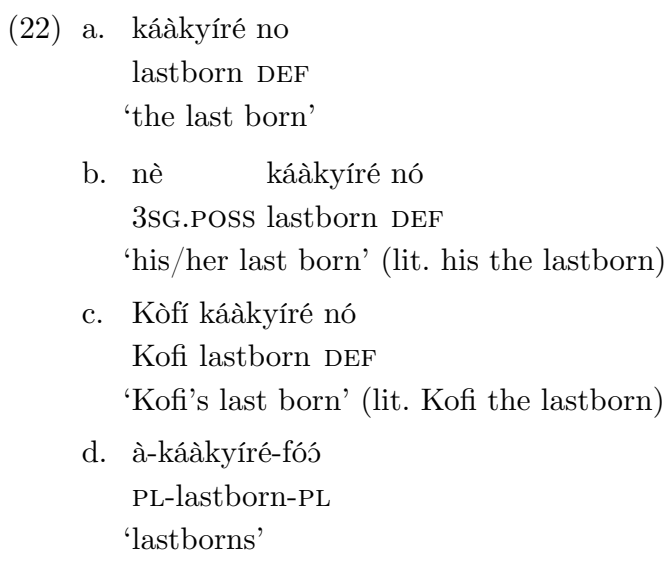

Regarding example (22d), it has been argued that the suffix [-fós] and its distinctly singular counterpart [-nyi] attach to nominal bases only to either form or pluralize human nouns and so any unit that serves as a base for -fóó suffixation, has to be a noun, prima facie (cf. Appah 2013a;b; 2017). The presence of -fós, therefore, shows that the $\mathrm{V}-\mathrm{N}$ construct ká-àkyíré 'lastborn' is indeed a noun.

\section{Conclusion}

In this paper, I have discussed three issues in the literature on $\mathrm{V}-\mathrm{N}$ compounds and shown how Akan answers the relevant questions. The issues relate to the syntactic category of the left-hand constituents and that of the compound, whether the formation of $\mathrm{V}-\mathrm{N}$ compounds is a matter of 
syntactic or morphology and how to distinguish $\mathrm{V}-\mathrm{N}$ compounds from VPs. I have shown that the left-hand constituent of the Akan V-N compound is indeed a verb, making the compound a $\mathrm{V}-\mathrm{N}$ compound. I have argued that, per the criteria in the literature, the formation of Akan V-N compounds has to be a matter of morphology and not syntax. However, I indicated that the second issue is subject to the theoretical orientation of the analyst and relevant for only models that assume a strict divide between morphology and syntax. Regarding the third issue, I have noted that, aside from the usual test for lexical integrity or syntactic atomicity, there are morphological, phonological and semantic basis for distinguishing between V-N compounds and VPs in Akan.

\section{References}

Abakah, Emmanuel Nicholas. 2006. The tonology of compounds in Akan. Languages and Linguistics 17. 1-33.

Ackema, Peter and Ad Neeleman. 2001. Competition between syntax and morphology. In J. Grimshaw, G. Legendre and S. Vikner (eds.) Optimality Theoretic syntax. Cambridge, MA: MIT Press. 29-60.

Ackema, Peter and Ad Neeleman. 2004. Beyond morphology. Interface conditions on word formation. Oxford: Oxford University Press.

Anderson, Jonathan C. 2013. Verb-internal compound formation in Akan. Journal of West African languages 60. 89-104.

Anderson, Stephen R. 1992. A-Morphous morphology. Cambridge: Cambridge University Press.

Anyidoho, Akosua. 1990. On tone in Akan compound nouns. Paper presented at the the 19th West African Languages Congress, University of Ghana, Legon.

Appah, Clement Kwamina Insaidoo. 2005. Action nominalization in Akan. In M. E. K. Dakubu and E. K. Osam (eds.) Studies in the languages of the Volta Basin: Proceedings of the Annual Colloquium of the Legon-Trondheim Linguistics Project. Accara: Linguistics Department, University of. 132-142.

Appah, Clement Kwamina Insaidoo. 2013a. The case against A-N compounding in Akan. Journal of West African languages 40. 73-87.

Appah, Clement Kwamina Insaidoo. 2013b. Construction morphology: Issues in Akan complex nominal morphology. Doctoral dissertation. Lancaster University.

Appah, Clement Kwamina Insaidoo. 2015. On the syntactic category of Akan compounds: A product-oriented perspective. Acta Linguistica Hungarica 62. 361-394.

Appah, Clement Kwamina Insaidoo. 2016. Akan verb-noun compounds. Italian Journal of Linguistics 28. 3-24.

Appah, Clement Kwamina Insaidoo. 2017. Personal attribute nominal construction in Akan: A Construction Morphology account. Legon Journal of the Humanities 28. $49-72$. 
Basciano, Bianca, Nancy Kula and Chiara Melloni. 2011. Modes of compounding in Bantu, Romance and Chinese. Rivista di linguistica 23. 203-249.

Bauer, Laurie. 1980. Deux problèmes au sujet des noms composés comprenant un premier élément verbal en français moderne. Le français moderne 48. 219-224.

Bauer, Laurie. 1983. English word-formation. Cambridge: Cambridge University Press.

Bauer, Laurie. 2001. Morphological productivity. Cambridge: Cambridge University Press.

Bisetto, Antonietta. 1999. Note sui composti vn dell'italiano. In P. Benincà, A. Mioni and L. Vanelli (eds.) Fonologia e morfologia dell'italiano e dei dialetti d'Italia. Roma: Bulzoni. 503-538.

Booij, Geert E. 2004. Constructions and the interface between lexicon and syntax. In H. H. Aertsen and G. Mike Steen (eds.) Words in their place. Festchrift for J. L. Mackenzie. Amsterdam: Vrije Universiteit. 275-282.

Booij, Geert E. 2009. Lexical integrity as a formal universal: A constructionist view. In S. Scalise, E. Magni and A. Bisetto (eds.) Universals of language today. Dordrecht: Springer. 83-100.

Booij, Geert E. 2010a. Construction morphology. Language and Linguistics Compass 4. $543-555$.

Booij, Geert E. 2010b. Construction morphology. Oxford: Oxford University Press.

Booij, Geert E. 2012a. Construction morphology, a brief introduction. Morphology 22. 343-346.

Booij, Geert E. 2012b. The grammar of words: An introduction to linguistic morphology (Third edition). Oxford: Oxford University Press.

Braun, Maria. 2009. Word-formation and creolisation: The case of Early Sranan. Berlin \& New York: Mouton de Gruyter.

Bresnan, Joan W. and Sam A. Mchombo. 1995. The lexical integrity principle: Evidence from Bantu. Natural Language \& Linguistic Theory 13. 181-254.

Chomsky, Noam. 1970. Remarks on nominalization. In R. A. Jacobs and P. S. Rosenbaum (eds.) Readings in English transformational grammar. Waltham: Ginn. 184-221.

Chomsky, Noam. 1995. The minimalist program. Cambridge, MA: MIT Press.

Christaller, Johannes Gottlieb. 1875. A grammar of the Asante and Fante language called Tshi (Chwee, Twi) based on the Akuapem dialect with reference to the other (Akan and Fante) dialects. Basel: Basel Evangelical Missionary Society.

Comrie, Bernard. 1976. The syntax of action nominals: A cross-linguistic study. Lingua 40. 177-201.

Contreras, Heles. 1985. Spanish exocentric compounds. In F. H. Nuessel (ed.) Current issues in Hispanic phonology and morphology. Bloomington: Indiana University Linguistics Club. 14-27.

Corbin, Danielle. 1992. Hypothèses sur les frontières de la composition nominale. Cahiers de grammaire 17. 25-55.

Desmets, Marianne and Florence Villoing. 2009. French VN lexemes: Morphological compounding in HPSG. Paper presented at the HPSG09 Conference, Georg-AugustUniversity at Göttingen.

Di Sciullo, Anna Maria and Edwin Williams. 1987. On the definition of word (Linguistic Inquiry Monograph 14). Cambridge, MA: MIT Press. 
Dixon, Robert Malcolm Ward and Alexandra Yurievna Aikhenvald (eds.). 2002a. Word. A cross-linguistic typology. Cambridge: Cambridge University Press.

Dixon, Robert Malcolm Ward and Alexandra Yurievna Aikhenvald. 2002b. Word: A typological framework. In Dixon \& Aikhenvald (2002a, 1-42).

Dolphyne, Florence Abena. 1988. The Akan (Twi-Fante) language: Its sound systems and tonal structure. Accra: Ghana Universities Press.

Fábregas, Antonio and Sergio Scalise. 2012. Morphology: From data to theories. Edinburgh: Edinburgh University Press.

Fradin, Bernard. 2005. On a semantically grounded difference between derivation and compounding. In W. U. Dressler, D. Kastovsky, O. E. Pfeiffer and F. Rainer (eds.) Morphology and its demarcations. Amsterdam \& Philadelphia: John Benjamins. 161-82.

Fradin, Bernard. 2009. IE, Romance: French. In Lieber \& Štekauer (2009, 417-435).

Gast, Volker. 2008. Verb-noun compounds in English and German. Zeitschrift für Angelistik und Amerikanistik 53. 269-282.

Gast, Volker. 2009. Verb-noun compounds in European languages. Hand-out of the talk given at the University of Erfurt, November 4, 2009. http://www.personal.uni-jena.de/ mu65qev/talks.html

Giegerich, Heinz J. 2004. Compound or phrase? English noun-plus-noun constructions and the stress criterion. English Language and Linguistics 8. 1-24.

Giegerich, Heinz J. 2005. Associative adjectives in English and the lexicon-syntax interface. Journal of Linguistics 41. 571-591.

Goldberg, Adele E. and Ray Jackendoff. 2004. The English resultative as a family of constructions. Language 80. 532-568.

Grimshaw, Jane. 1990. Argument structure (Linguistic Inquiry Monograph 18). Cambridge, MA: MIT Press.

Halle, Morris. 1973. Prolegomena to a theory of word-formation. Linguistic Inquiry 4. 3-16.

Halle, Morris and Alec Marantz. 1993. Distributed morphology and the pieces of inflection. In K. Hale and S. J. Keyser (eds.) The view from building 20. Essays in linguistics in honor of Sylvain Bromberger. Cambridge, MA: MIT Press. 111-176.

Halle, Morris and Alec Marantz. 1994. Some key features of Distributed Morphology. In A. Carnie and H. Harley (eds.) MIT Working Papers in Linguistics 21: Papers on phonology and morphology. Cambridge, MA: MIT Press. 275-88.

Harley, Heidi and Rolf Noyer. 1999. Distributed morphology. GLOT International 4. 3-9. Jenssen, Theo. 2012. Compositionality: Its historic context. In Werning et al. (2012, 19-46).

Jurafsky, Daniel. 1992. An on-line computational model of human sentence interpretation: A theory of the representation and use of linguistic knowledge. Doctoral dissertation. University of California, Berkeley.

Koptjevskaja-Tamm, Maria. 1993. Nominalizations. London: Routledge.

Koptjevskaja-Tamm, Maria. 2006. Nominalization. In K. Brown (ed.) Encyclopedia of language and linguistics. 2nd edition. Amsterdam: Elsevier. 652-659.

Kornfeld, Laura Malena. 2009. IE, Romance: Spanish. In Lieber \& Štekauer (2009, 436-452).

Langacker, Ronald W. 2005. Construction Grammars: Cognitive, radical, and less so. In M. S. P. Cervel and F. J. R. de Mendoza Ibáñez (eds.) Cognitive linguistics: Internal dynamics and interdisciplinary interaction. Berlin \& New York: Mouton de Gruyter. $101-159$. 
Lieber, Rochelle. 1980. On the organization of the lexicon. Doctoral dissertation. Massachusetts Institute of Technology.

Lieber, Rochelle. 1992. Deconstructing morphology: Word formation in syntactic theory. Chicago: Chicago University Press.

Lieber, Rochelle and Sergio Scalise. 2007. The Lexical Integrity Hypothesis in a new theoretical universe. In G. E. Booij, L. Ducceschi, B. Fradin, E. Guevara, A. Ralli and S. Scalise (eds.) On-line proceedings of the Fifth Mediterranean Morphology Meeting (MMM5), Fréjus 15-18 September 2005. Bologna: University of Bologna. 1-24.

Lieber, Rochelle and Pavol Štekauer (eds.). 2009. The Oxford handbook of compounding. Oxford: Oxford University Press.

Lyons, John. 1968. Introduction to theoretical linguistics. Cambridge: Cambridge University Press.

Marantz, Alec. 1997. No escape from syntax: Don't try morphological analysis in the privacy of your own lexicon. University of Pennsylvania Working Papers in Linguistics 4. 201-225.

Marchand, Hans. 1969. The categories and types of present-day English word-formation: A synchronic-diachronic approach (Second, completely revised and enlarged edition). München: C. H. Beck.

Masini, Francesca. 2009. Phrasal lexemes, compounds and phrases: A constructionist perspective. Word Structure 2. 254-271.

Melloni, Chiara. 2006. Logical polysemy in word formation: E and R suffixes. Lingue e linguaggio 2. 281-308.

Melloni, Chiara. 2007. Polysemy in word formation: The case of deverbal nominals. Doctoral dissertation. Universita Degli Studi Di Verona.

Melloni, Chiara. 2010. Action nominals inside: Lexical-semantic issues. In M. Rathert and A. Alexiadou (eds.) The semantics of nominalizations across languages and frameworks. Berlin \& New York: De Gruyter Mouton. 141-168.

Obeng, Samuel Gyasi. 2009. Akan deverbal nouns. In S. G. Obeng (ed.) Topics in descriptive and African linguistics: Essays in honor of distinguished professor Paul Newman. München: LINCOM Europa. 96-110.

Plag, Ingo. 2003. Word-formation in English. Cambridge: Cambridge University Press.

Rainer, Franz and Solelad Varela. 1992. Compounding in Spanish. Rivista di linguistica 4. $117-42$.

Ralli, Angela and Melita Stavrou. 1998. Morphology-syntax interface: A/N compounds versus A/N constructs in Modern Greek. In G. E. Booij and J. van Marle (eds.) Yearbook of morphology 1997. Dordrecht: Kluwer. 243-264.

Rohrer, Christian. 1977. Die Wortzusammensetzung im modernen Französisch. Tübingen: Gunter Narr.

Scalise, Sergio. 1984. Generative morphology. Dordrecht: Foris.

Scalise, Sergio. 1992. Compounding in Italian. Rivista di Linguistica 4. 175-98.

Scalise, Sergio, Antonietta Bisetto and Emiliano Guevara. 2005. Selection in compounding. In W. U. Dressler, D. Kastovsky, O. E. Pfeiffer and F. Rainer (eds.) Morphology and its demarcations. Amsterdam \& Philadelphia: John Benjamins. 133-50.

Scalise, Sergio and Emiliano Raúl Guevara. 2005. The lexicalist approach to word-formation and the notion of the lexicon. In Stekauer \& Lieber (2005, 147-187). 
Selkirk, Elizabeth O. 1982. The syntax of words (Linguistic Inquiry Monograph 7). Cambridge, MA: MIT Press.

Spencer, Andrew. 1991. Morphological theory. An introduction to word structure in generative grammar. Cambridge, MA \& Oxford: Blackwell.

Spencer, Andrew. 2005. Word-formation and syntax. In Štekauer \& Lieber (2005, 73-97).

Stekauer, Pavol and Rochelle Lieber (eds.). 2005. Handbook of word-formation. Dordrecht: Springer.

Szabó, Zoltán Gendler. 2012. The case for compositionality. In Werning et al. (2012, 64-80).

Tollemache, F. 1945. Le parole composte nella lingua italiana. Roma: Rores.

Varela, Salvador. 1990. Composición nominal y estructura temática. Revista española de linguistica 1. 56-81.

Werning, Markus, Wolfram Hinzen and Edouard Machery (eds.). 2012. Handbook of compositionality. Oxford: Oxford University Press.

Williams, Edwin S. 1978. Across-the-board rule application. Linguistic Inquiry 9. 31-43.

Yoon, Jiyoung. 2009. Constructional meanings of verb-noun compounds in Spanish: Limpiabotas vs. tientaparedes. Language Sciences 31. 507-530.

Zager, David. 1981. On orientation or, constraining false analogy. Linguistics 19. 1107-1131. 
